\title{
FECAL CALPROTECTIN: levels for the ethiological diagnosis in Brazilian patients with gastrointestinal symptoms
}

\author{
Lorete Maria da Silva KOTZE ${ }^{1}$, Renato Mitsunori NISIHARA ${ }^{2,3}$, Sandra Beatriz MARION1, \\ Murilo Franco CAVASSANI ${ }^{2}$ and Paulo Gustavo KOTZE ${ }^{1}$
}

\begin{abstract}
Background - Determination of fecal calprotectin can provide an important guidance for the physician, also in primary care, in the differential diagnosis of gastrointestinal disorders, meanly between inflammatory bowel diseases and irritable bowel syndrome. Objectives - The aims of the present study were to prospectively investigate, in Brazilian adults with gastrointestinal complaints, the value of fecal calprotectin as a biomarker for the differential diagnosis between functional and organic disorders and to correlate the concentrations with the activity of inflammatory bowel diseases. Methods - The study included consecutive patients who had gastrointestinal complaints in which the measurement levels of fecal calprotectin were recommended. Fecal calprotectin was measured using a Bühlmann (Basel, Switzerland) ELISA kit. Results - A total of 279 patients were included in the study, with median age of 39 years (range, 18 to 78 years). After clinical and laboratorial evaluation and considering the final diagnosis, patients were allocated into the following groups: a) Irritable Bowel Syndrome: 154 patients (102 female and 52 male subjects). b) Inflammatory Bowel Diseases group: 112 patients; 73 with Crohn's disease; 38 female and 35 male patients; 52.1\% (38/73) presented active disease, and $47.9 \%$ (35/73) had disease in remission and 39 patients with ulcerative colitis; 19 female and 20 male patients; 48.7\% (19/39) classified with active disease and 49.3\% (20/39) with disease in remission. A significant difference $(P<0.001)$ was observed between the median value of fecal calprotectin in Irritable Bowel Syndrome group that was $50.5 \mu \mathrm{g} / \mathrm{g}$ (IQR=16 - $294 \mu \mathrm{g} / \mathrm{g}) ; 405 \mu \mathrm{g} / \mathrm{g}$ (IQR=29 - $1980 \mu \mathrm{g} / \mathrm{g})$ in Crohn's disease patients and $457 \mu \mathrm{g} / \mathrm{g}(\mathrm{IQR}=25-1430 \mu \mathrm{g} / \mathrm{g})$ in ulcerative colitis patients. No difference was observed between the values found in the patients with Crohn's disease and ulcerative colitis. Levels of fecal calprotectin were significantly lower in patients with inflammatory bowel diseases in remission when compared with active disease $(P<0.001)$. Conclusions - The present study showed that the determination of fecal calprotectin assists to differentiate between active and inactive inflammatory bowel diseases and between inflammatory bowel diseases and irritable bowel syndrome.
\end{abstract}

HEADINGS - Biological markers. Inflammatory bowel disease. Irritable bowel syndrome. Gastrointestinal diseases, diagnosis.

\section{INTRODUCTION}

Calprotectin is an abundant calcium and zinc-binding protein predominantly present in the cytoplasm of cells involved in pathogen defense, such as neutrophil granulocytes, monocytes, and macrophages. Calprotectin shows bacteriostatic and fungistatic properties in vitro, which underline its function in pathogen attack. In neutrophil granulocytes, it accounts for as much as $60 \%$ of the cytosolic protein ${ }^{(1,7)}$.

In concert with C-reactive protein (CRP), erythrocyte sedimentation rate (ESR), and stool culture, the measurement of fecal calprotectin (FC) may be useful as a screening test in all subjects reporting gastrointestinal problems (such as abdominal pain, diarrhea, and bloating) very frequent and common to several diseases ${ }^{(14,15,25,33)}$. FC presents characteristics that permit to discriminate between inflammatory and noninflammatory disorders ${ }^{(5)}$. A negative result in a patient without alarm symptoms could avoid endoscopy (3-fold in adults and by $35 \%$ in children and adolescents), whereas a positive result can prioritize invasive and expensive procedures such as endoscopic examination and intestinal biopsies ${ }^{(14,30)}$. Determination of FC can provide an important guidance for the physician, also in primary care ${ }^{(19)}$, in the differential diagnosis of gastrointestinal disorders, mainly between inflammatory bowel diseases (IBD) and irritable bowel syndrome (IBS) ${ }^{(3,10)}$.

FC also may be valuable in determining whether clinical symptoms in patients with known IBD are caused by disorder flares or noninflammatory complications, underlying $\mathrm{IBS}^{(2)}$, and in providing objective evidence of response to treatment ${ }^{(10)}$. Patient's

Declared conflict of interest of all authors: LMSK is a speaker for abbvie. PK is a speaker and consultant for Abbvie, Janssen-Cilag, Ferring, Pfizer and Takeda. Disclosure of funding: no funding received

Serviço de Gastroenterologia e Cirurgia Colorretal, Hospital Universitário Cajuru, Pontifícia Universidade Católica do Paraná; ${ }^{2}$ Departamento de Medicina, Faculdade Serviço de Gastroenterologia e Cirurgia Colorretal, Hospital Universitário Cajuru, Ponti
Evangélica; ${ }^{3}$ Departamento de Medicina, Universidade Positivo. Curitiba, PR, Brasil.

Correspondence: Prof. Renato Nisihara. Rua João Azolin, 660. CEP: 82015-040 - Curitiba, PR, Brasil. E-mail: renatonisihara@up.edu.br; renatomitsu@yahoo.com.br 
symptoms can be an important indication of inflammation and disease activity but are subjective and may be influenced by other non-inflammatory features of the disease such as intestinal strictures or bile salt malabsorption. Activity indexes are cumbersome to use in clinical practice and still rely heavily on subjective patient symptoms ${ }^{(10,23)}$. Serological and hematological tests don't always correlate well with symptoms and activity indexes. Imaging studies are useful in localizing intestinal inflammation but are not cost-effective, have suboptimal sensitivity and/or specificity, can be invasive or can expose the patient to ionizing radiation ${ }^{(13)}$. Thus, a simple, rapid, sensitive, inexpensive, noninvasive biomarker to detect and monitor intestinal inflammation in IBD is needed. FC may present these characteristics ${ }^{(10)}$. Additionally, FC measurement can minimize the number of false-positive results and reduce the number of unnecessary biopsies ${ }^{(31)}$.

The level of calprotectin in feces is approximately six times higher than that in the serum. This makes stool testing more sensitive, in addition to the higher specificity for intestinal diseases $^{(25)}$. Abdominal discomfort is a common cause of consultation in primary care and gastroenterology departments and presents a clinical challenge even for experienced physicians ${ }^{(19,31)}$. Recently, Kopylov et al. ${ }^{(11)}$ published a review article concerning the clinical utility of fecal biomarkers, including calprotectin, for the diagnosis and management of IBD. There is scarce information about the use of this test in Brazilian patients ${ }^{(18,32)}$.

The aims of the present study were to prospectively investigate, in Brazilian adults with gastrointestinal complaints, the value of $\mathrm{FC}$ as a biomarker for the differential diagnosis between functional and organic disorders and to correlate the concentrations with the activity of IBD.

\section{METHODS}

This study was approved by local Ethics Research Committee and all patients signed a written consent and were followed at the Gastroenterology and Colorectal Surgery units of Cajuru University Hospital, Catholic University of Paraná, Curitiba, Paraná, Brazil, and associated private practice.

The study included consecutive patients who had gastrointestinal complaints in which the measurement levels of FC were recommended. All the patients included in this study were attended in specialist service consecutively.

FC was tested on the same day when the fecal samples were obtained. The fecal samples were tested using a Bühlmann (Basel, Switzerland) ELISA kit. After a short extraction procedure using $50 \mathrm{mg}$ of feces and $2.5 \mathrm{~mL}$ of extraction buffer, the selective measurement of $F C$ by sandwich ELISA was performed. A monoclonal capture antibody specific to $\mathrm{FC}$ heterodimeric and polymeric complexes is coated onto the microtiter plate. Calibrators, controls and patients extracts diluted 1:50 were incubated at room temperature for 30 minutes. After a washing step a detection antibody conjugated to horseradish peroxidase was added. After incubation and a further washing step, tetramethylbenzidine was added, followed by a stopping reaction. The absorption was measured at $450 \mathrm{~nm}$ with Bio-tek Instruments, Inc. ELX 800 (USA). In according with manufacturer instructions, values below $50 \mu \mathrm{g} / \mathrm{g}$ are not indicative of inflammation in the gastrointestinal tract. Levels between 50-200 $\mu \mathrm{g} / \mathrm{g}$ are considered undetermined and suggestive of repeating measurement and performing further investigations. Values above $200 \mu \mathrm{g} / \mathrm{g}$ are indicative of active organic disease with inflammation of the gastrointestinal tract.

Patients were diagnosed as IBS according to Rome III criteria $^{(23)}$; CD and UC were diagnosed by clinical, imaging, endoscopic and histological findings ${ }^{(12)}$. The activity of IBD was classified in remission, mild, moderate or severe activity according to Physician Global Assessment (PGA) ${ }^{(22,27)}$. In the PGA criteria, patients who had no abdominal pain, blood in stool, severe diarrhea and no palpable mass, without leaks, no weight loss and laboratory tests without changes, were classified as in remission. Patients with mild abdominal pain for several times a week, diarrhea and blood in stool in small amounts or infrequently, active fistula and weight loss, but without abdominal mass and laboratory tests without changes were classified in mild activity. Clinical signs of moderate abdominal pain, significant fatigue maybe secondary to IBD, active fistula or perianal disease, a significant weight loss and increased presence of abdominal tenderness or small abdominal mass occur in patients with moderate activity, besides, anemia, hypoalbuminemia and elevated inflammatory markers. Finally, the ones with severe disease activity had significant abdominal pain, severe and/or nocturnal diarrhea, inflammatory aspect and bleeding secondary to IBD, severe fatigue, impairment of daily activities, active fistula or other perianal features, significant weight loss and abdominal mass. In addition to that, anemia, hypoalbuminemia and elevated inflammatory markers were also observed in these patients. Due to the reduced number of cases, the patients were classified in remission/mild disease or with active disease (moderate/severe disease). The miscellanea group was diagnosed and confirmed by appropriated conventional tests.

Data of these populations were compared using Fisher and chi-squared tests for nominal data and Mann-Whitney test for numeric data. Central tendency was expressed in median and interquartile range (IQR). Calculation was done with the software Graphpad Prism version 4.0 and the adopted significance of $5 \%$.

\section{RESULTS}

A total of 279 patients were included in the study, with median age of 39 years (range, 18 to 78 years) (Table 1). After clinical and laboratorial evaluation and considering the final diagnosis, patients were allocated into the following groups:

a) IBS group: 154 patients (102 female and 52 male subjects).

b) IBD group: 112 patients; 73 with Crohn's disease (CD) (38 female and 35 male patients; 52.1\% (38/73) presented active disease, and $47.9 \%(35 / 73)$ had disease in remission) and 39 patients with ulcerative colitis 
(UC) (19 female and 20 male patients; 48.7\% (19/39) classified with active disease and 49.3\% (20/39) with disease in remission).

c) Miscellanea group: 13 patients $(1$ with mesenteric angina, 6 with celiac disease, 1 with lymphoma, 3 with diverticular disease, and 2 with acute intestinal infections).

Table 1 shows the demographic data of the studied patients and the detected levels of FC.

A significant difference $(P<0.001)$ was observed between the median value of FC in IBS group that was $50.5 \mu \mathrm{g} / \mathrm{g}$ $(\mathrm{IQR}=16-294 \mu \mathrm{g} / \mathrm{g}) ; 405 \mu \mathrm{g} / \mathrm{g}(\mathrm{IQR}=29-1980 \mu \mathrm{g} / \mathrm{g})$ in $\mathrm{CD}$ patients and $457 \mu \mathrm{g} / \mathrm{g}(\mathrm{IQR}=25-1430)$ in UC patients. No difference was observed between the values found in the patients with CD and UC. Levels of FC were significantly lower in patients with IBD in remission when compared with active disease $(P<0.001)$.

Figure 1 shows the levels of FC in patients with IBS and IBD and also the correlation concerning the activity of the inflammatory disorder.

The FC levels of the miscellanea group of patients are as follows: mesenteric angina $830 \mu \mathrm{g} / \mathrm{g}$; celiac disease, IQR $=78$ $253 \mu \mathrm{g} / \mathrm{g}$; lymphoma, $1370 \mu \mathrm{g} / \mathrm{g}$; diverticular disease, IQR $=38$ $-519 \mu \mathrm{g} / \mathrm{g}$; and acute intestinal infections, 1170 and $1274 \mu \mathrm{g} / \mathrm{g}$.

No difference in the FC levels was observed in comparing gender or age in the studied patients.

\section{DISCUSSION}

Inflammation is characterized by an increased activity of immune cells, which releases pathogen-attacking substances such as calprotectin. In intestinal inflammation, the barrier function of the intestinal wall is compromised, and neutrophil granulocytes migrate through the wall into the intestinal lumen. This leads to elevated calprotectin levels in the stool ${ }^{(31)}$. The level of FC correlated directly to the number of neutrophil granulocytes in the intestinal lumen. However, FC is specifically elevated in IBD, such as CD and UC, and in smaller extent in other entities (neoplasias ${ }^{(20)}$, polyps, and diverticular disease ${ }^{(29)}$. Jensen et al. ${ }^{(9)}$, reported that $\mathrm{FC}$ is equally sensitive in $\mathrm{CD}$, affecting both small bowel and colon. These correlations also make FC a specific and sensitive marker in indicating intestinal inflammation ${ }^{26,31)}$.

The medium levels of FC concentration in healthy adults were reported by several authors: Thjodleifsson et al. ${ }^{(26)}$ referred $20 \mu \mathrm{g} / \mathrm{g}$ in 163 individuals; Poullis et al. ${ }^{(20)}, 27 \mu \mathrm{g} / \mathrm{g}$ in 320 cases; and Roseth et al. ${ }^{(21)}, 30 \mu \mathrm{g} / \mathrm{g}$ in 124 individuals. In the present investigation, 154 IBS patients had median levels of $50.5 \mu \mathrm{g} / \mathrm{g}$ (minimum $16 \mu \mathrm{g} / \mathrm{g}$ and maximum $294 \mu \mathrm{g} / \mathrm{g}$ ), in accordance to the previously referred studies.

In relation to FC levels in IBD patients, Vieira et al. ${ }^{(32)}$, in a single study conducted in Brazil, showed mean levels of $686 \mu \mathrm{g} / \mathrm{g}$ (range, 52.9 to $2542.8 \mu \mathrm{g} / \mathrm{g}$ ) in patients with IBD, not specified. In our study, the median concentration of calprotectin for CD was $405.0 \mu \mathrm{g} / \mathrm{g}$, and that for UC was $457.0 \mu \mathrm{g} / \mathrm{g}$, both significantly increased as compared to the IBS group (Table 1, Figure 1), distinguishing IBD from functional gastrointestinal disorder as reported by Manz et

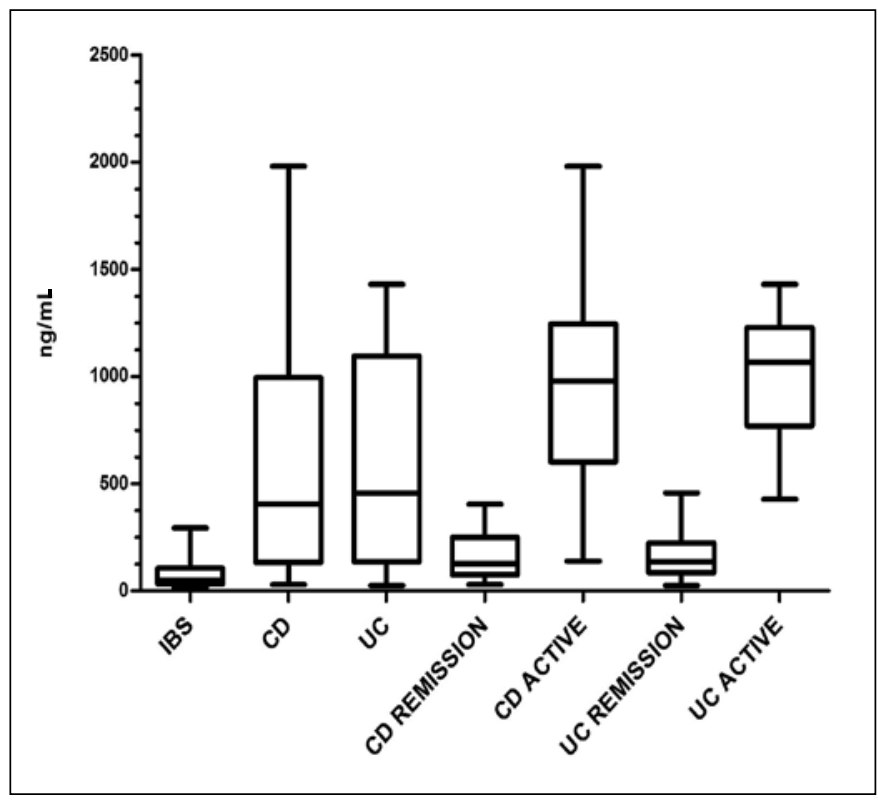

FIGURE 1. Calprotectin levels in the studied patients IBS: irritable bowel syndrome; CD: Crohn's disease; UC: ulcerative colitis

TABLE 1. Fecal calprotectin levels in studied groups

\begin{tabular}{|c|c|c|c|c|c|c|c|}
\hline & $\begin{array}{c}\text { IBS } \\
\mathrm{n}=154 \\
\end{array}$ & $\begin{array}{c}\mathrm{CD} \\
\mathrm{n}=73\end{array}$ & $\begin{array}{c}\mathrm{UC} \\
\mathrm{n}=39\end{array}$ & $\begin{array}{c}\mathrm{CD} \\
\text { remission } \\
\mathrm{n}=35\end{array}$ & $\begin{array}{c}\text { CD active } \\
\mathrm{n}=38\end{array}$ & $\begin{array}{c}\mathrm{UC} \\
\text { remission } \\
\mathrm{n}=19\end{array}$ & $\begin{array}{c}\text { UC active } \\
\mathrm{n}=20\end{array}$ \\
\hline Male & $52(33.8 \%)$ & $35(48 \%)$ & $20(51.3 \%)$ & $17(48.6 \%)$ & $18(47.4 \%)$ & $10(52.6 \%)$ & $10(50 \%)$ \\
\hline Female & $102(66.2 \%)$ & $38(52 \%)$ & $18(48.7 \%)$ & $18(51.4 \%)$ & $20(52.6 \%)$ & $9(47.4 \%)$ & $10(50 \%)$ \\
\hline Minimum (ng/ml) & 16 & 29 & 25 & 29 & 139 & 25 & 428 \\
\hline Maximum (ng/mL) & 294 & 1980 & 1430 & 405 & 1980 & 457 & 1430 \\
\hline Median (ng/mL) & 50.5 & 405.0 & 457.0 & 126.0 & 979.5 & 136 & 1067.0 \\
\hline Mean $(\mathrm{ng} / \mathrm{mL})$ & 72.6 & 567.8 & 582.8 & 168.6 & 935.5 & 169.4 & 975.6 \\
\hline Std. deviation & 54.1 & 482.2 & 471 & 119.2 & 387 & 126.1 & 308.9 \\
\hline Lower $95 \% \mathrm{CI}$ of mean & 64 & 455.2 & 430.1 & 127.6 & 808.2 & 108.6 & 831 \\
\hline Upper $95 \% \mathrm{CI}$ of mean & 81.2 & 680.3 & 735.5 & 209.5 & 1062.7 & 230.2 & 1120.1 \\
\hline
\end{tabular}

IBS: Irritable Bowel Syndrome; CD: Crohn's disease; UC: Ulcerative colitis 
al. ${ }^{(15)}$ However, it is still not possible to recommend the use of biological markers for the diagnosis of IBS. Although the results showing statistical significance in the sample studied, is necessary emphasize the importance of clinical diagnosis of IBS through Rome III criteria ${ }^{(23)}$. Additionally, determination of FC in CD could distinguish remission/mild activity (126 $\mu \mathrm{g} / \mathrm{g})$ from moderate/severe $(979.5 \mu \mathrm{g} / \mathrm{g})$ and in UC remission/ mild $(136.0 \mu \mathrm{g} / \mathrm{g})$ from moderate/severe $(1067.0 \mu \mathrm{g} / \mathrm{g})$ disease. There were no differences between the two IBD studies as a whole or in relation to activity. The similar levels of FC between IBS and both IBD groups when in remission was noteworthy (Figure 1). These data are in accordance with those of the authors from different countries ${ }^{(15,24)}$, deducing that IBD in Brazil can be similar unless different environment factors could play a role.

Naismith et al..$^{(17)}$, using the largest prospective dataset in the literature, provide evidence that adults with quiescent $C D$ with an FC level below $240 \mu \mathrm{g} / \mathrm{g}$ are unlikely to relapse within 12 months. Thus, this level could become a therapeutic target for physicians treating $\mathrm{CD}$ patients who are in clinical remission when attending the outpatient clinic ${ }^{(28)}$. Therefore, FC determination can also be used to predict flares of $\operatorname{IBD}^{(6,8)}$. Our results are in accordance with this report, as both $\mathrm{CD}$ and UC in remission expressed inferior levels (lower than $127.6 \mu \mathrm{g} / \mathrm{g}$ and higher than $209.5 \mu \mathrm{g} / \mathrm{g}$ for DC; lower than $108.6 \mu \mathrm{g} / \mathrm{g}$ and higher than $230.2 \mu \mathrm{g} / \mathrm{g}$ for UC) (Table 1).

FC should not be thought to be a marker of organic disease: rather, it is a marker of neutrophil intestinal inflammation $^{(4)}$. This fact was demonstrated in two cases of intestinal infection in the present research. Many common organic intestinal diseases, such as celiac disease ${ }^{(16)}$, diverticular disease $^{(29)}$, colorectal carcinoma ${ }^{(20)}$, microscopic colitis, and allergic colitis, are not uniformly characterized by significant neutrophil infiltrate, so FC can be detected but in levels lower than those in $\mathrm{IBD}^{(25)}$. The findings of the patients from the miscellanea group corroborated this fact.

Therefore, a negative FC test should not be interpreted as a clean bill of intestinal health but rather as the absence of significant neutrophilic intestinal inflammation. This will be most helpful in differentiating patients with IBD from those with IBS and also in determining whether clinical symptoms in patients with known IBD are caused by disease flares, noninflammatory complications, or underlying IBD $^{(2,10)}$. Because FC concentration has been shown to correlate with endoscopic and histological inflammation in IBD, it could be a useful marker with which to follow response to treatment $t^{(13,21,33)}$. The results of the present study suggest that the test be used as a guide to evaluate the efficacy of the treatment in each case, and monitor tightly the disease course, as referred by Kopylov et al. ${ }^{(11)}$

It is important to inform that laboratories should be aware of the lack of the assay standardization, as demonstrated by the between-assay variability by Whitehead et al. ${ }^{(34)}$ Different results can be obtained when using commercial kits. In our experience, FC had the same critical steps as extraction, affinity of monoclonal antibody, and calibrators that can influence the sensitivity and/or specificity of tests.

In summary, the present study showed that the determination of FC assists to differentiate between active and inactive IBD and between IBD and IBS.

\section{Author contribution}

Kotze LMS, Marion SB and Kotze PG managed all patients included, and gave significant intellectual contribution to the article. Nisihara RM performed all tests and did statistical analysis. Cavassani MF did data collection. Kotze LMS, Nisihara RM, Marion SB, Cavassani MF and Kotze PG wrote the manuscript draft. All authors reviewed the article and gave final approval.

Kotze LMS, Nisihara RM, Marion SB, Cavassani MF, Kotze PG. Calprotectina fecal: níveis para o diagnóstico etiológico em pacientes brasileiros com sintomas gastrointestinais. Arq Gastroenterol. 2015,52(1):50-4

RESUMO - Contexto - A calprotectina fecal é um biomarcador que pode fornecer informações importantes para o médico, inclusive no atendimento primário, no diagnóstico diferencial de distúrbios gastrointestinais, principalmente as doenças inflamatórias intestinais e a síndrome do intestino irritável. Objetivos - Investigar prospectivamente, em adultos brasileiros com queixas gastrointestinais, o valor da calprotectina fecal como biomarcador para o diagnóstico diferencial de distúrbios funcionais e orgânicos e correlacionar as concentrações com a atividade de doenças inflamatórias intestinais. Método - O estudo incluiu pacientes consecutivos que apresentavam queixas gastrointestinais e que a dosagem da calprotectina fecal foi recomendada. A dosagem da calprotectina fecal foi obtida utilizando-se o kit ELISA Buhlmann, (Basel, Suiça). Resultados - Um total de 279 foram incluídos no estudo, com idade média de 39 anos (variando entre 18 a 78 anos). Após avaliação clínica e laboratorial, e considerando o diagnóstico final, os pacientes foram alocados nos seguintes grupos: a) Grupo Síndrome do Intestino Irritável: 154 pacientes (102 do sexo feminino e 52 indivíduos do sexo masculino). b) grupo Doenças Inflamatórias Intestinais: 112 pacientes; 73 com doença de Crohn; 38 do sexo feminino e 35 pacientes do sexo masculino; 52,1\% (38/73) apresentavam doença ativa, e 47,9\% (35/73) tiveram a doença em remissão e 39 pacientes com retocolite ulcerativa; 19 do sexo feminino e 20 pacientes do sexo masculino; 48,7\% (19/39) classificadas com a doença ativa e 49,3\% (20/39) com a doença em remissão. Foi observada uma diferença significativa $(P<0,001)$ entre o valor médio de calprotectina fecal no grupo Síndrome do Intestino Irritável que foi de $50,5 \mu \mathrm{g} / \mathrm{g}$ (16 a $294 \mu \mathrm{g} / \mathrm{g}) ; 405 \mu \mathrm{g} / \mathrm{g}(29$ a $1980 \mu \mathrm{g} / \mathrm{g})$, em pacientes com doença de Crohn e $457 \mu \mathrm{g} / \mathrm{g}(25 \mathrm{a} 1430 \mu \mathrm{g} / \mathrm{g})$, em pacientes com retocolite ulcerativa. Não foram observadas diferenças entre os valores encontrados nos pacientes com doença de Crohn e retocolite ulcerativa. Os níveis de calprotectina fecal foram significativamente menores nos pacientes com doenças inflamatórias intestinais em remissão, quando comparado com a doença ativa $(P<0,001)$. Conclusão - O presente estudo mostrou que a determinação da calprotectina fecal ajuda na diferenciação entre doenças inflamatórias intestinais ativas e inativas e entre doenças inflamatórias intestinais e síndrome do intestino irritável. Além disso, ela pode ser utilizada como um guia para classificar a atividade da doença, monitorar o tratamento, prever recaídas, e sugerir se os sintomas clínicos são da doença de base ou de alguma comorbidade funcional.

DESCRITORES - Marcadores biológicos. Doenças inflamatórias intestinais. Síndrome do intestino irritável. Gastroenteropatias, diagnóstico. 


\section{REFERENCES}

1. Abraham BP, Kane, S. Fecal markers: calprotectin and lactoferrin. Gastroenterol Clin North Ame. 2012;41(2):483-95.

2. Berrill JW, Green JT, Hood K, Campbell AK. Symptoms of irritable bowe syndrome in patients with inflammatory bowel disease: examining the role of sub-clinical inbflammation and the impact on clinical assessment of disease activity. Aliment Pharmacol Ther. 2013;38(1):44-51.

3. Carroccio A, Iacono G, Cottone M, Di Prima L, Cartabellota F, Cavataio F, et al Diagnostic accuracy of fecal calprotectin assay in distinguishing organic causes of chronic diarrhea from irritable bowel syndrome: a prospective study in adults and children. Clin Chem. 2003;49(6 Pt 1):861-7.

4. Chen CC, Huang JL, Chuang CJ, Kong MS. Fecal calprotectin as a correlative marker in clinical severity of infectious diarrhea and usefulness in evaluating bacterial or viral pathogens in children. J Pediatr Gastroenterol Nutr. 2012;55(5):541-7.

5. Costa F, Mumolo MG, Bellini M, Romano MR, Ceccarelli L, Arpe P, et al. Role of faecal calprotectin as non-invasive marker of intestinal inflammation. Dig Liver Dis. 2003; 35(9):642-7.

6. D'Incà R, Dal Pont E, Di Leo V, Benazzato L, Martinato M, Lamboglia F, et al. Can calprotectin predict relapse risk in inflammatory bowel disease? Am J Gastroenterol. 2008;103(8):2007-14.

7. Gaya DR, Mackenzie JF. Faecal calprotectin: a bright future for assessing disease activity in Crohn's disease. QJM. 2002;95(9):557-8.

8. Ho GT, Lee HM, Brydon G, Ting T, Hare N, Drummond H, et al. Fecal calprotectin predicts the clinical course of acute severe ulcerative colitis. Am J Gastroenterol. 2009;104(3):673-8.

9. Jensen MD, Kjeldsen J, Nathan T. Fecal calprotectin is equally sensitive in Crohn's disease affecting the small bowel and colon. Scand J Gastroenterol. 2011;46(6):694-700.

10. Konikoff MR, Denson LA. Role of fecal calprotectin as a biomarker of intestinal inflammation in inflammatory bowel disease. Inflamm Bowel Dis. 2006;12(6):524-4

11. Kopylov U, Rosenfeld G, Bressler B, Seidman E. Clinical utility of fecal biomarkers for the diagnosis and management of inflammatory bowel disease. Inflamm Bowel Dis. 2014;20(4):742-56.

12. Kotze LMS, Kotze PG, Kotze LR. Doença de Crohn. In: Dani R, Gastroenterologia Essencial. 4th ed. Guanabara-Koogan; 2011. p.347-80.

13. Lewis JD. The utility of biomarkers in the diagnosis and therapy of inflammatory bowel disease. Gastroenterology. 2011; 140:1817-26.

14. Licata A, Randazzo C, Cappello M, Calvaruso V, Butera G, Florena AM, et al Fecal calprotectin in clinical practice: a noninvasive screening tool for patients with chronic diarrhea. J Clin Gastroenterol. 2012;46(6);504-8.

15. Manz M, Burri E, Rothen C, Tchanguizi N, Niederberger C, Rossi 1, et al. Value of fecal calprotectin in the evaluation of patients with abdominal discomfort: an observational study. BMC Gastroenterol. 2012;12:5.

16. Montalto M, Santoro L, Curigliano V, D’Onofrio F, Cammarota G, Panunzi S Ricci R, Gallo A, Grieco A, Gasbarrini A, Gasbarrini G. Faecal calprotectin concentrations in untreated coeliac patients. Scand J Gastroenterol. 2007;42(8):957-61.

17. Naismith GD, Smith LA, Barry SJE, Munro JI, Laird S, Rankin K, et al. A prospective evaluation of the predictive value of faecal calprotectin in quiescent Crohn's disease. J Crohns Colitis, 2014;8(9):1022-9.
18. Nogueira IM, Miszputen SJ, Ambrogini Jr O, Artigiani-Neto R, Carvente CT, Zanon MI. Assessment of the response of patients with Crohn's disease to biological therapy using non-invasive markers: lactoferrin and calprotectin. Arq Gastroenterol. 2013;50(2):130-7.

19. Pavlidis P, Chedgy FJ, Tibble JA. Diagnostic accuracy and clinical application of faecal calprotectin in adult patients presenting with gastrointestinal symptoms in primary care. Scand J Gastroenterol. 2013;48(9):1048-54.

20. Poullis A, Foster R, Shetty A, Fagerhol MK, Mendall MA. Bowel inflammation as measured by fecal calprotectin: a link between life style factors and colorectal cancer risk. Cancer Epidemiol Biomarkers Prev. 2004;13(2):279-84.

21. Røseth AG, Aadland E, Jahnsen J, Raknerud N. Assessment of disease activity in ulcerative colitis by fecal calprotectin, a novel granulocyte marker protein. Digestion. 1997;58(2):176-80.

22. Sands BE. From symptom to diagnosis: Clinical distinctions among various forms of intestinal inflammation. Gastroenterology. 2004;126(6):11518-32.

23. Spiller RC, Thompson WG. Roma III. Transtornos intestinais. Arq Gastroenterol. 2012; 49(supl 1):39-50.

24. Summerton CB, Longlands MG, Wiener K, Shreeve DR. Faecal calprotectin a marker of inflammation throughout the intestinal tract. Eur J Gastroenterol Hepatol. 2002; 14(8):841-5.

25. Sutherland $\mathrm{AD}^{1}$, Gearry RB, Frizelle FA. Review of fecal biomarkers in inflammatory bowel disease. Dis Colon Rectum. 2008;51(8)1283-91.

26. Thjodleifsson B, Sigthorsson G, Cariglia N, Reynisdottir I, Gudbjartsson DF, Kristjansson K, ey al. Subclinical intestinal inflammation: an inherited abnormality in Corhn's disease relatives? Gastroenterology. 2003;124(7):1728-37.

27. Tibble JA, Sigthorsson G, Bridger S, Fagerhol MK, Bjarnason I. Surrogate markers of intestinal inflammation are predictive of relapse in patients with inflammatory bowel disease. Gastroenterology. 2000;119(1):15-22.

28. Turner D, Griffiths AM, Veerman G, Johanns J, Damaraju L, Blank M, Hyams $\mathrm{J}$. Endoscopic and clinical variables that predict sustained remission in children with ulcerative colitis treated with infliximab. Clin Gastroenterol Hepatol. 2013;11(11):1460-5.

29. Tursi A. Biomarkers in diverticular disease of the colon. Dig Dis. 2012; 30:12-8

30. Van Rheenen OF, Van de Vijver E, Fidler V. Faecal calprotectin for screening of patients with suspected inflammatory bowel disease: diagnostic meta-analysis. BMJ. 2010;341:c3369.

31. Vermeire S, Van Assche G, Rutgeerts P. Laboratory markers in IBD: Useful, magic or unnecessary toys? Gut. 2006;55(3):426-31.

32. Vieira A, Fang CB, Rolim EG, Klug WA, Steinwurz F, Rossini LGB, Candelaria PA. Inflammatory bowel disease activity assessed by fecal calprotectin and lactoferrin: correlation with laboratory parameters, clinical, endoscopic and histological indexes. BMC Res Notes. 2009;2:221-7.

33. Wang S, Wang Z, Shi H, Heng L, Juan W, Yuan B, Wu X, Wang F. Faecal calprotectin concentration in gastrointestinal diseases. J Int Med Res. 2013;41(4):1357-61.

34. Whitehead SJ, French J, Brookes MJ, Ford C, Gama R. Between - assay variability of faecal calprotectin enzyme-linked immunosorbent assay kits. Ann Clin Biochem. 2013;50(Pt 1):53-61.

Received 13/6/2014

Accepted 11/8/2014 